\title{
Nitrogen Metabolism in Preterm Infants Fed Human Donor Breast Milk: the Possible Essentiality of Glycine
}

\author{
A. A. JACKSON, ${ }^{(58)}$ J. C. L. SHAW, A. BARBER, AND M. H. N. GOLDEN \\ Tropical Metabolism Research Unit, University of the West Indies [A.A.J., M.H.N.G.], Mona, Kingston, Jamaica, \\ Faculty of Clinical Sciences, Department of Paediatrics, University College London [J.C.L.S., A. B.], The Rayne \\ Institute, University Street, London, WCIE 6JJ
}

\section{Summary}

Nitrogen metabolism was studied in three preterm infants (mean gestation 32 wk) by the method of consecutive metabolic balance. The absorption and retention of nitrogen from breast milk was measured, and protein turnover, synthesis, and breakdown were calculated from isotopic plateau of urinary urea and ammonia using an intermittent oral administration of ${ }^{15} \mathrm{~N}$-glycine. Weight gain and nitrogen retention were compared with the weight gain and nitrogen accumulated for a foetus of equivalent gestational age in utero.

The average composition of the milk was $289 \pm 19 \mathrm{KJ} \mathrm{dl}^{-1}$ and $1.44 \pm 24 \mathrm{~g}$ protein $\mathrm{dl}^{-1}$. The intake of energy was $572 \pm 61 \mathrm{KJ}$ $\mathrm{kg}^{-1}$ day $^{-1}$ and of nitrogen $447 \pm 99 \mathrm{mg} \mathrm{kg}^{-1}$ day $^{-1}$. Stool output of nitrogen was $100 \pm 32 \mathrm{mg} \mathrm{kg}^{-1}$ day $^{-1}$ giving an absorption of $348 \pm 78 \mathrm{mg} \mathrm{kg}^{-1}$ day $^{-1}$, as urinary excretion was $91 \pm 17 \mathrm{mg}$ $\mathrm{kg}^{-1} \mathrm{day}^{-1}$ retained nitrogen was $256 \pm 71 \mathrm{mg} \mathrm{kg}^{-1}$ day $^{-1}$, or $56 \%$ of intake.

The specific weight gain was $15.6 \pm 2.6 \mathrm{~g} \mathrm{~kg}^{-1} \mathrm{day}^{-1}$ and $53 \%$ of this comprised lean tissue (range 34 to $89 \%$ ). In all but one study the postnatal retention of nitrogen fell far short of calculated in utero accumulation.

The results of protein turnover were surprising. In six of the eight studies urinary urea failed to become enriched at all. Protein turnover calculated from the ammonia plateau was $1.94 \pm 0.54 \mathrm{~g}$ nitrogen $\mathrm{kg}^{-1}$ day $^{-1}$, synthesis $10.9 \pm 3.4 \mathrm{~g}$ protein $\mathrm{kg}^{-1}$ day $^{-1}$ and breakdown $9.3 \pm 3.4 \mathrm{~g}$ protein $\mathrm{kg}^{-1}$ day $^{-1}$.

It is concluded that the amino acid composition of breast milk may be inappropriate for supporting rates of lean tissue deposition equivalent to in utero accumulation.

\section{Speculation}

Endogenous synthesis of glycine in preterm infants may be inadequate to meet the needs of growth, making glycine a semiessential amino acid in this situation. The glycine content of breast milk may be insufficient to meet the requirements of preterm infants.

The results of a number of investigations have shown that preterm infants grow less well and retain less nitrogen when fed human breast milk, than they do when given certain cow's milk formulae with a higher protein content $(5,10,11,18-20,36,46)$. Though the formulae studied differed in a number of respects from breast milk, it has been concluded that the difference in growth is due principally to the absence of sufficient protein in breast milk, and it has been inferred from measurements of weight gain $(5,10,19,20)$, longitudinal growth $(5,11)$, and plasma protein and urea concentration (18) that preterm infants probably require about 3.5 to $4.5 \mathrm{~g}$ protein $\mathrm{kg}^{-1} \mathrm{day}^{-1}$ for optimum growth (8).

This high protein requirement is in part explained by the high rate of nitrogen accumulation that is characteristic of foetal growth between 24 and $36 \mathrm{wk}$ gestation (42). However, if a preterm infant did lay down lean tissue at a rate comparable to that occurring in utero the net protein utilisation on the protein intake given above would only be about $45 \%$. Since the absorption of nitrogen is not inadequate $(6,20)$, it seems likely that the utilisation of absorbed protein is inefficient. One reason for this could be a defect in the quality of the protein, especially when the particular requirements of the foetus for individual amino acids are considered (56). Although it was not the initial purpose of the present investigation the data presented here support the hypothesis that the high protein requirements of preterm infants may be the result of inadequate amounts of glycine in the diet. It is postulated that the circumstances that might make glycine limiting for growth in the preterm infant are the exceptionally high demands of growth, the relatively small amounts present in breast milk (56), and immaturity of the enzymes involved in glycine synthesis $(44,45)$.

The initial purpose of the study was to measure protein turnover in the preterm infants, because the two reports of such measurements in the literature using ${ }^{15} \mathrm{~N}$-glycine as a label seemed irreconcilable. Nicholson (32) using the single dose method of San Pietro and Rittenberg (40) found rates of protein synthesis comparable to adult values obtained by the same method. Pencharz et al. (37), on the other hand, using the continuous infusion method of Picou and Taylor-Roberts (38) found values for protein synthesis in preterm infants to be about eight times higher than in young adult subjects. The discrepancy may be explained partly on a methodologic basis. The San Pietro and Rittenberg (40) model depends on instantaneous and uniform labeling of the precursor pool for both protein and urea synthesis, an assumption we have shown to be invalid (22), while Pencharz et al. (37) had difficulty in identifying the isotopic plateau, possibly because the period of urine collection was limited to 30 to $36 \mathrm{hr}$.

In the present study we have used the method of Picou and Taylor-Roberts (38) and have determined the rise of isotope to plateau in both urinary urea and ammonia over a period of $72 \mathrm{hr}$. The results go some way to reconciling the conflicting results of Nicholson (32) and Pencharz et al. (37).

\section{PATIENTS AND METHODS}

\section{PATIENTS}

The subjects of the study were three preterm infants who were admitted to the intensive care unit of University College Hospital. Details of the infants are given in Table 1. Infant $\mathrm{C}$ developed 
Table 1. Details of infants

\begin{tabular}{cccc}
\hline Subject & $\begin{array}{c}\text { Birth weight } \\
(\mathrm{g})\end{array}$ & $\begin{array}{c}\text { Gestation } \\
(\mathrm{wk})\end{array}$ & Wt percentile $^{\mathbf{t}^{\prime}}$ \\
\hline A & 1140 & 32 & $<10$ th \\
B & 1055 & 33 & $<10$ th \\
C & 1400 & 31.5 & 25 th \\
\hline
\end{tabular}

${ }^{1}$ Lubchenko et al. (28).

hydrocephalus (probably due to a small intraventricular haemorrhage) which was treated by intermittent removal of cerebrospinal fluid by the lumbar route. A ventriculo-peritoneal shunt was inserted, subsequently.

The reasons for the study and the procedures involved were explained to the parents and their agreement obtained. The study was approved by the ethical committee of University College Hospital.

\section{METABOLIC BALANCE TECHNIQUES}

The metabolic balances (9) were started on the 9 th or 10th day of life when weight gain had been resumed. The balances lasted $72 \mathrm{hr}$ and were repeated at 7- to 10-day intervals.

The infants were nursed in incubators. They were fed hourly through polypropylene nasogastric feeding tubes of $0.96 \mathrm{~mm}$ OD. When the infants were able to suck milk was given by bottle every $2 \mathrm{hr}$.

\section{MILK AND ISOTOPE ADMINISTRATION}

The infants were fed pooled pasteurised human breast milk, except in study B2 when SMA (John Wyeth \& Brothers Ltd., Taplon, Maidenhead, England) was given. Sufficient milk for a 72-hr period was placed in a stainless steel mixer, vitamins A, D, and $C$ (Abidec $\left.1 \mathrm{ml} \mathrm{day}{ }^{-1}\right)$, and ferrous sulphate $\left(2.5 \mathrm{mg} . \mathrm{Fe} \mathrm{kg}^{-1}\right.$ day $^{-1}$ ) were added, together with sufficient ${ }^{15} \mathrm{~N}$ glycine $(95.2$ atoms percent excess, B.O.C. Ltd., Prochem., London, England) to give about $0.1 \mathrm{mg}{ }^{15} \mathrm{~N} \mathrm{~kg}^{-1} \mathrm{day}^{-1}$. The milk was well mixed and portions were taken for analysis. If the infant was tube fed, the milk was drawn up into disposable polystyrene syringes, and if bottle fed, the milk was measured out into acid washed sterile glass feeding bottles. The full syringes or bottles were weighed and frozen at $-20^{\circ} \mathrm{C}$ until required. The amount of milk given was determined by subtraction after weighing the used syringes or bottles and caps together with any residual milk remaining in them. Spillages, regurgitations, and vomits were collected onto ashless filter papers placed under the infant's head, which were preserved for analysis. A record of accidents was kept by the nursing staff. The cerebrospinal fluid removed during balances $\mathrm{C}_{2}$ and $\mathrm{C}_{3}$ was analysed and an appropriate correction applied.

\section{STOOL COLLECTION}

Stool was collected between carmine markers on to $11.0-\mathrm{cm}$ ashless filter paper (Whatman) held in place by polyethylene tie pants (Lewis Wolff Griptight Ltd., Selly Oak, Birmingham, England). Only distilled water and filter papers were used for cleaning the infant's bottom. Any leakage of stool was collected on a 24$\mathrm{cm}$ ashless filter paper placed between the infant and the bedding.

\section{URINE COLLECTION}

Urine was collected by continuous aspiration (27) into a chilled weighed flask which was changed every $4 \mathrm{hr}$. A borate buffer trap was incorporated into the circuit to collect any ammonia resulting from bacterial decomposition.

\section{ANALYTICAL METHODS}

The filter papers containing regurgitated milk and stool were counted and their numbers recorded. They were digested in concentrated hydrochloric acid and homogenised with a Teflon homogeniser. The nitrogen content of milk, urine, and stool were measured in duplicate by the micro Kjeldahl method. The protein content of breast milk was calculated by multiplying total nitrogen by 6.38 . The energy content of a freeze-dried specimen of milk was measured in triplicate by Ballistic bomb calorimetry (Gallenkamp Ltd., Christopher St., London, England). The urea and ammonia content of the urine was measured by the Berthelot reaction (24).

The $\mathrm{pH}$ of each urine sample was measured and a $10-\mathrm{ml}$ sample taken, acidified, and freeze-dried before being transported in a sealed container to the Tropical Metabolism Research Unit, Jamaica. The urine was reconstituted to $10 \mathrm{ml}$ with deionised water. Ammonia nitrogen was isolated by entrainment with air. Urea nitrogen was then liberated as ammonia by the enzymic reaction with urease and isolated for mass spectrometry (23). The residual nitrogen in the urine was isolated after Kjeldahl digestion and prepared for mass spectrographic analysis. The enrichment of urinary ammonia, urea, and residual nitrogen was measured as nitrogen gas in a dual-collector isotope-ratio mass spectrometer (Micromass 602C, V. G. Micromass, Dinsford, Cheshire, England) after being liberated in vacuo with alkaline hypobromite (48). The enrichment of the samples of nitrogen gas derived from the three sources was calculated against the abundance of the corresponding nitrogen in a zero sample of urine collected between 0 and $4 \mathrm{hr}$ before the administration of the isotope. Plateau values were determined by visual inspection. Protein turnover was calculated by the method of Picou and Taylor-Roberts (38) from the plateau enrichment of urinary ammonia (53).

\section{PROTEIN TURNOVER (FIG. 1)}

The method of Picou and Taylor-Roberts (38) assumes a single metabolic pool of nitrogen from which protein is synthesised and the end products of nitrogen metabolism, e.g., urea or ammonia, formed. The pool is assumed to remain constant in size during the period of study. The protein turnover (flux or $\dot{Q}$ ) is therefore defined as the sum of all nitrogen entering $(I+B$, from the diet or protein breakdown) or the sum of all nitrogen leaving $(E+Z$ to excretion or protein synthesis) the metabolic pool. In practice ${ }^{15} \mathrm{~N}$-glycine is administered at a constant rate and the ratio of ${ }^{15} \mathrm{~N}$ to ${ }^{14} \mathrm{~N}$ is measured in the urea or ammonia (53) present in timed specimens of urine. When the ratio becomes constant plateau is said to be reached and it is assumed that the enrichment in the metabolic nitrogen pool is the same as any product being formed from that pool.

$$
\text { i.e., } \frac{\dot{\mathrm{d}}}{\dot{\mathrm{Q}}}=\frac{\dot{\mathrm{e} u}}{\dot{\mathrm{E} u}}=\frac{\dot{\mathrm{e} N H_{3}}}{\dot{\mathrm{E} N H_{3}}} \text { and } \dot{\mathrm{Q}}=\frac{\dot{\mathrm{d}}}{\frac{\dot{\mathrm{e} u}}{\dot{\mathrm{E} u}}}
$$

where $d=$ rate of administration of isotopic nitrogen

$$
\begin{gathered}
\frac{\dot{\mathrm{eu}}}{\dot{\mathrm{Eu}}} \text { and } \frac{\dot{\mathrm{e} N H_{3}}}{\mathrm{ENH}_{3}} \begin{array}{c}
\text { are the enrichment in urea or } \\
\text { ammonia at plateaux, } \mathrm{S} .
\end{array} \\
\dot{\mathrm{Q}}=\frac{\dot{\mathrm{d}}}{\mathrm{S}}
\end{gathered}
$$

\section{INTRAUTERINE WEIGHT GAIN AND THE NITROGEN} ACCUMULATION OF FOETUS

In order to evaluate the results of the balances, estimates of intrauterine weight gain and nitrogen accumulation were made. The method given below was used to remove the bias in the data of Widdowson and Dickerson (55), introduced by the unusually large size of their full term fetuses, and to enable us to estimate weight gain and nitrogen retention for fetuses growing along different percentiles. From the data of Widdowson and Dickerson 
(55) and of Kelly et al. (25) it can be shown that nitrogen concentration of the foetus rises in a linear manner between 18 and 40 wk gestation and corresponds to the equation.

Nitrogen $\mathrm{mg} \mathrm{kg}^{-1}$ foetus ${ }^{-1}=0.308 \times$ gestation $(w k)+7.25(r$ $=0.84$ ).

Using the mean nitrogen concentration at different gestations derived from this equation, and the fetal body weights published by Lubchenko et al. (28) we have calculated the nitrogen content of foetuses growing along the 10th, 50th, and 90th percentiles and from these data using the methods outlined by Shaw (42), have calculated the daily rate of accumulation of nitrogen by a fetus in utero between 24 and 36 wk gestation. These estimates together with the specific growth rates derived directly from the data of Lubchenko et al. (28) are given in Table 2.

\section{RESULTS}

\section{COMPOSITION OF MILK}

The results of the analyses of the milk are given in Table 3 . The milk in balance AI had the lowest energy content and the highest protein energy to total energy ratio. The values for SMA fell in the middle of the range for protein and energy.

\section{ENERGY INTAKE AND NITROGEN BALANCE}

The energy intakes and the results of the nitrogen balances are given in Table 4 . The energy intakes varied but averaged $572 \mathrm{~kJ}$ (136 kcal) $\mathrm{kg}^{-1} \mathrm{day}^{-1}$, and only in balance $\mathrm{C}_{2}$ was the energy intake less than $500 \mathrm{~kJ} \mathrm{~kg}^{-1} \mathrm{day}^{-1}$.

The results of the nitrogen balances were in agreement, the

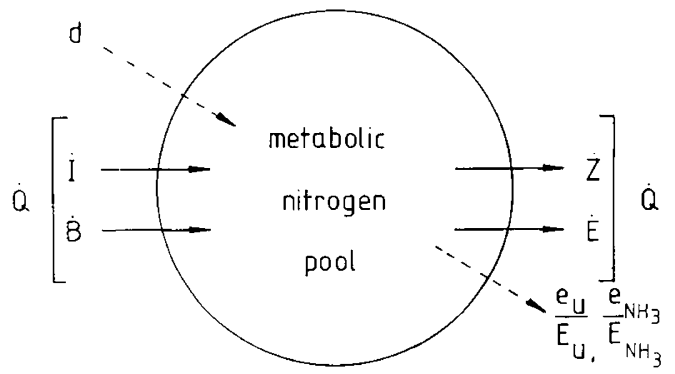

Fig. 1. Model of Picou and Taylor-Roberts (38) for measuring protein turnover where: $\dot{\mathcal{I}}$, rate of dietary nitrogen intake; $\dot{\mathrm{B}}$, rate of nitrogen coming from protein breakdown; $\dot{Z}$, rate of nitrogen going to protein synthesis; $\dot{E}$, rate of nitrogen excretion; $\dot{Q}$, rate of nitrogen turnover, flux; $\dot{d}$, rate of administration of labeled nitrogen; èu, rate of excretion of labelled nitrogen as urea; $\dot{\mathrm{E}}_{\mathrm{u}}$, rate of excretion of urea nitrogen; ${ }^{\dot{\mathrm{e}}} \mathrm{NH}_{3}$, rate of excretion of labeled nitrogen as ammonia; ${ }^{\dot{\mathrm{E}}} \mathrm{NH}_{3}$, rate of excretion of ammonia nitrogen.

Table 2. Calculated rate of accumulation of nitrogen and wt gain by the human foetus growing along the 10th, 50th and 90th

\begin{tabular}{|c|c|c|c|}
\hline $\begin{array}{l}\text { Gestation } \\
\text { (wk) }\end{array}$ & $\begin{array}{c}10 \% \\
\left(\mathrm{Nitrogen}^{-1} \mathrm{day}^{-1}\right) \\
\mathrm{mg} \mathrm{kg}^{-1} \text { d }^{-1}\end{array}$ & $\begin{array}{c}50 \% \\
(\text { Nitrogen } \\
\left.\mathrm{mg} \mathrm{kg}^{-1} \mathrm{day}^{-1}\right)\end{array}$ & $\begin{array}{c}90 \% \\
\left(\mathrm{Nitrogen}^{-1} \mathrm{mg} \mathrm{kg}^{-1} \text { day }^{-1}\right)\end{array}$ \\
\hline 24 & 267 & 252 & 226 \\
\hline 26 & 279 & 261 & 236 \\
\hline 28 & 293 & 274 & 247 \\
\hline 30 & 304 & 284 & 256 \\
\hline 32 & 315 & 294 & 265 \\
\hline 34 & 325 & 305 & 274 \\
\hline 36 & 342 & 320 & 289 \\
\hline Wt gain & $\mathrm{g} \mathrm{kg}_{15.6}^{-1} \mathrm{day}^{-1}$ & $\begin{array}{c}\mathrm{g} \mathrm{kg}^{-1} \mathrm{day}^{-1} \\
14.4\end{array}$ & $\begin{array}{c}\mathrm{g} \mathrm{kg}^{-1} \mathrm{day}^{-1} \\
12.2\end{array}$ \\
\hline
\end{tabular}

Table 3. Details of the balances and composition of the diet

\begin{tabular}{|c|c|c|c|c|c|c|}
\hline & $\begin{array}{c}\text { Age } \\
\text { (days) }\end{array}$ & $\begin{array}{c}\mathrm{Wt} \text { at } \\
\text { midpoint }\end{array}$ & Diet & $\begin{array}{l}\text { Energy } \\
(\mathrm{kJ} / \mathrm{dl})\end{array}$ & $\begin{array}{c}\text { Protein }^{1} \\
(\mathrm{~g} / \mathrm{dl})\end{array}$ & $\mathrm{PE} \%^{2}$ \\
\hline $\mathrm{Al}$ & $9-11$ & 1126 & $\mathrm{EBM}^{3}$ & 260 & 1.97 & 12.7 \\
\hline $\mathrm{A} 2$ & $16-18$ & 1243 & $\mathrm{EBM}$ & 306 & 1.5 & 8.2 \\
\hline $\mathrm{A} 3$ & $23-25$ & 1394 & EBM & 304 & 1.36 & 7.5 \\
\hline B1 & $10-12$ & 1051 & EBM & 279 & 1.40 & 8.4 \\
\hline B2 & $20-22$ & 1230 & SMA & 291 & 1.43 & 8.2 \\
\hline $\mathrm{Cl}$ & $10-12$ & 1302 & EBM & 277 & 1.29 & 7.8 \\
\hline $\mathrm{C} 2$ & $21-23$ & 1540 & EBM & 277 & 1.16 & 7.0 \\
\hline $\mathrm{C} 3$ & $30-32$ & 1730 & EBM & 316 & 1.32 & 7.0 \\
\hline Mean & & & & 289 & 1.44 & 8.4 \\
\hline \pm S.D. & & & & \pm 19 & \pm 24 & \\
\hline
\end{tabular}

${ }^{1}$ Calculated as nitrogen $\times 6.38$.

${ }^{2}$ Percentage of total energy derived from protein.

${ }^{3}$ EBM, expressed breast milk.

highest retention being in balance Al where protein intake was highest. Figure 2 gives nitrogen retention as a function of nitrogen intake after subtraction of $10 \mathrm{mg}$ nitrogen $\mathrm{kg}^{-1} \mathrm{day}^{-1}$ from retention for unmeasured losses. This modest estimate was selected on purpose so as to avoid exaggerating the differences between in utero and postnatal accumulation rates. The least squares regression line drawn through the points is described by the following equation.

nitrogen retention $\mathrm{mg} \mathrm{kg}^{-1} \mathrm{day}^{-1}$

$$
=\text { nitrogen intake } \mathrm{mg} \mathrm{kg}^{-1} \mathrm{day}^{-1} \times 0.7+67.4(r=0.98)
$$

The intercept on the y axis gives an estimate of the obligatory nitrogen losses, $67 \mathrm{mg} \mathrm{kg}^{-1}$ day $^{-1}$, and the intercept on the $\mathrm{x}$ axis gives an estimate of the nitrogen required to maintain zero balance, namely $96 \mathrm{mg} \mathrm{kg}^{-1} \mathrm{day}^{-1}$. The intake, after maintenance requirements had been met, was utilised with an efficiency of $70 \%$.

\section{WEIGHT GAIN AND NITROGEN RETENTION}

Details of weight gain (Fig. 3) and utilisation of retained protein are given in Table 5. The mean specific weight gain was $15.6 \mathrm{~g}$ $\mathrm{kg}^{-1}$ day $^{-1}$ and this is the same as the estimated specific weight gain for a foetus growing along the 10th centile given in Table 2.

Table 6 compares the postnatal nitrogen accumulation with that estimated for a foetus of equivalent gestation growing along the 10 th percentile. In all but one case (balance Al) the values lay below the estimated intrauterine rate. It follows that the gain in lean body mass (Table 5) is less in absolute amount and per unit of body weight than that occurring in utero, and it suggests that fat is being deposited in preference to lean tissue.

\section{PROTEIN TURNOVER}

Details of plateau enrichment of urinary urea, ammonia, and residual nitrogen with ${ }^{15} \mathrm{~N}$ are given in Table 7 . In all the studies plateau enrichment was reached in urinary ammonia by 12 to 20 hr. However in six of the eight studies urinary urea failed to become significantly enriched at all. In study Al enrichment of urea did occur and it was not different from the enrichment of ammonia. In $\mathrm{Cl}$ the urea plateau occurred at $30 \mathrm{hr}$ but was only $70 \%$ of the ammonia plateau. An example of this is given in Figure 4.

If the urea plateau had been used to calculate protein turnover, an infinitely high value would have been obtained in the six studies where there was no enrichment because the demoninator in the equation $\dot{Q}=\frac{\dot{\mathrm{d}}}{\mathrm{S}}$ would be zero (see "Patients and Methods"), and in $\mathrm{Cl}$ the value would have been $150 \%$ that calculated from the ammonia plateau. In Al urea and ammonia 
Table 4. Details of energy intake and nitrogen balance

\begin{tabular}{|c|c|c|c|c|c|c|c|}
\hline \multirow[b]{2}{*}{ Study } & \multicolumn{2}{|c|}{ Intake } & \multicolumn{2}{|c|}{ Output nitrogen } & \multirow{2}{*}{$\begin{array}{c}\text { Absorbed } \\
\text { nitrogen } \\
\left(\mathrm{mg} \mathrm{kg}^{-1} \mathrm{day}^{-1}\right)\end{array}$} & \multirow{2}{*}{$\begin{array}{c}\text { Retained } \\
\text { nitrogen } \\
\left(\mathrm{mg} \mathrm{kg}^{-1} \mathrm{day}^{-1}\right)\end{array}$} & \multirow{2}{*}{$\begin{array}{c}\text { Retained } \\
\text { nitrogen } \\
(\%)\end{array}$} \\
\hline & $\begin{array}{c}\text { Energy } \\
\left(\mathrm{kJ} \mathrm{kg}^{-1} \text { day }^{-1}\right)\end{array}$ & $\begin{array}{c}\text { Nitrogen } \\
\left(\mathrm{mg} \mathrm{kg}^{-1} \text { day }^{-1}\right)\end{array}$ & $\begin{array}{c}\text { Stool } \\
\left(\mathrm{mg} \mathrm{kg}^{-1} \mathrm{day}^{-1}\right)\end{array}$ & $\begin{array}{c}\text { Urine } \\
\left(\mathrm{mg} \mathrm{kg}^{-1} \mathrm{day}^{-1}\right)\end{array}$ & & & \\
\hline Al & 548 & 652 & 145 & 104 & 507 & 404 & 62 \\
\hline A2 & 616 & 474 & 96 & 85 & 378 & 293 & 62 \\
\hline A3 & 595 & 418 & 76 & 114 & 342 & 228 & 55 \\
\hline $\mathrm{B} 1$ & 583 & 459 & 108 & 79 & 350 & 271 & 59 \\
\hline B2 & 589 & 453 & 80 & 113 & 372 & 259 & 57 \\
\hline $\mathrm{Cl}$ & 506 & 370 & 88 & 82 & 283 & 200 & 54 \\
\hline $\mathrm{C} 2$ & 475 & 312 & 57 & 75 & 255 & 177 & 57 \\
\hline $\mathrm{C} 3$ & 666 & 438 & 146 & 74 & 293 & 216 & 40 \\
\hline Mean & 572 & 447 & 100 & 91 & 348 & 256 & 56 \\
\hline$\pm \mathrm{S} . \mathrm{D}$ & 61 & 99 & 32 & 17 & 78 & 71 & 7 \\
\hline
\end{tabular}

${ }^{1}$ Operative net protein utilisation.

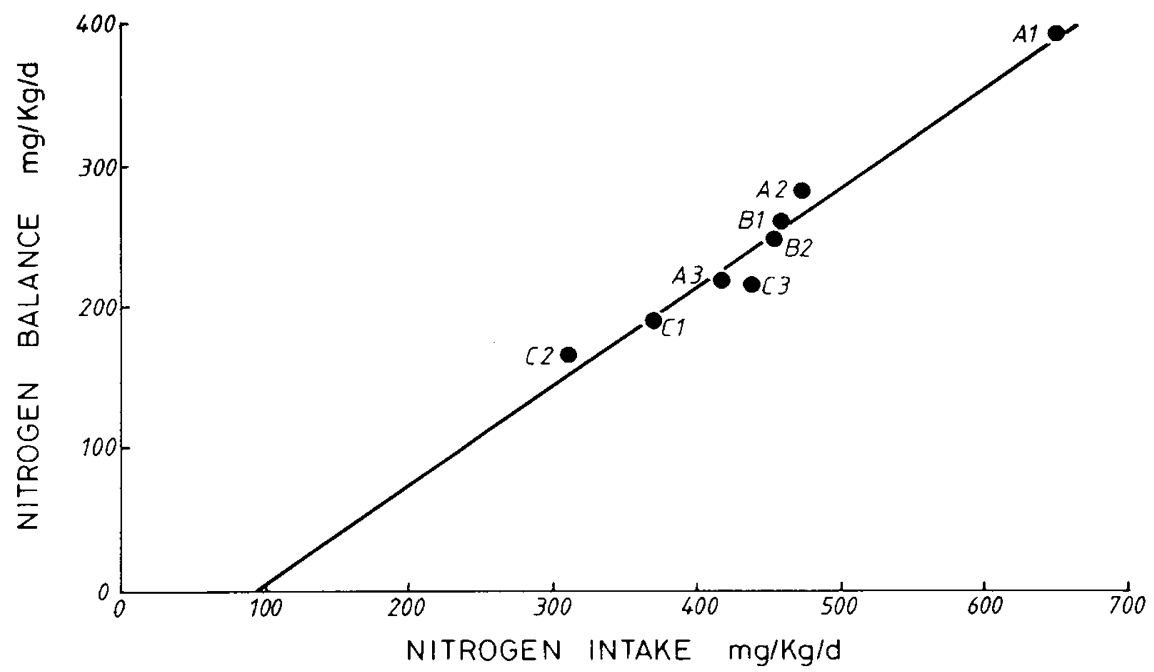

Fig. 2. Nitrogen balance and nitrogen intake for all the infants, allowing $10 \mathrm{mg}$ nitrogen $\mathrm{kg}^{-1} \mathrm{day}^{-1}$ for insensible losses. Nitrogen balance $=0.7 \times$ intake $+67.4(r=0.98)$.

Table 5. Wt gain and efficiency of utilisation of retained nitrogen

\begin{tabular}{cccc}
\multicolumn{4}{c}{ for lean tissue deposition } \\
\hline Study & $\begin{array}{c}\text { Specific } \\
\text { wt gain } \\
\left(\mathrm{g} \mathrm{kg}^{-1} \text { day }^{-1}\right)\end{array}$ & $\begin{array}{c}\text { Retained } \\
\text { protein' } \\
\left(\mathrm{g} \mathrm{kg}^{-1} \mathrm{day}^{-1}\right)\end{array}$ & $\begin{array}{c}\text { Lean tissue/wt gain } \times 100^{2} \\
(\%)\end{array}$ \\
\hline A1 & 16 & 2.52 & 78 \\
A2 & 10 & 1.83 & 89 \\
A3 & 15 & 1.42 & 46 \\
B1 & 19 & 1.69 & 45 \\
B2 & 16 & 1.62 & 50 \\
& & & \\
C1 & 18 & 1.25 & 34 \\
C2 & 16 & 1.11 & 36 \\
C3 & 14 & 1.34 & 48 \\
& 15.6 & 1.60 & 53 \\
Mean & 2.6 & 0.44 & 20 \\
\pm S.D. & & & \\
\hline
\end{tabular}

${ }^{1}$ Calculated by multiplying nitrogen retention $\times 6.25$.

${ }^{2}$ Lean tissue calculated as protein retained $\times 5$.

gave the same result. The values for protein turnover calculated from the plateau enrichment of urinary ammonia (54) are given in Table 8. The average turnover for the group was $1.94 \mathrm{~g}$ nitrogen $\mathrm{kg}^{-1}$ day $^{-1}$. The mean rate of synthesis was $10.6 \mathrm{~g}$ protein $\mathrm{kg}^{-1}$ day $^{-1}$ and the mean rate of breakdown $9.3 \mathrm{~g}$ protein $\mathrm{kg}^{-1}$ day $^{-1}$. The dietary protein, therefore, represents $25 \%$ of total turnover. The proportion of turnover going to synthesis was $86 \%$.

\section{DISCUSSION \\ MILK}

In this study pasteurised expressed human milk was used in seven of the eight balances and in the one balance where SMA was used the results were no different. The breast milk used in balance Al had a low energy and a high protein content giving it a protein energy ratio similar to that reported for milks of mothers who have delivered preterm infants $(2,3,21,41)$. The energy and protein contents of the milks used in the remaining balances were very similar and the average energy intake in particular seemed to be adequate $\left[572 \pm 61 \mathrm{~kJ}(137 \pm 15 \mathrm{kcal}) \mathrm{kg}^{-1}\right.$ day ${ }^{-1}$ (Table 4). Since we have reported absorption coefficients for fat of 80 to $90 \%$ for infants of this weight given breast milk (43), it can be inferred that the absorbed energy was of the order of $500 \mathrm{~kJ}$ (120 kcal) $\mathrm{kg}^{-1} \mathrm{day}^{-1}$ or more.

\section{NITROGEN BALANCE, MAINTENANCE REQUIREMENTS, AND OBLIGATORY NITROGEN LOSSES}

The mean nitrogen retention (Table 4) was very similar to that reported by Gordon et al. (20) and Pencharz et al. (37). Insensible losses of nitrogen from sweat and skin were measured by Synder- 
man et al. (46) in four infants and the average loss was $27 \mathrm{mg} \mathrm{kg}^{-1}$ day $^{-1}$. The estimates of Pencharz et al. (37) were $15.2 \mathrm{mg} \mathrm{kg}^{-1}$ day $^{-1}$. We have taken a value of $10 \mathrm{mg} \mathrm{kg}^{-1}$ day $^{-1}$ which we regard as a minimum value. Using this value our estimates of

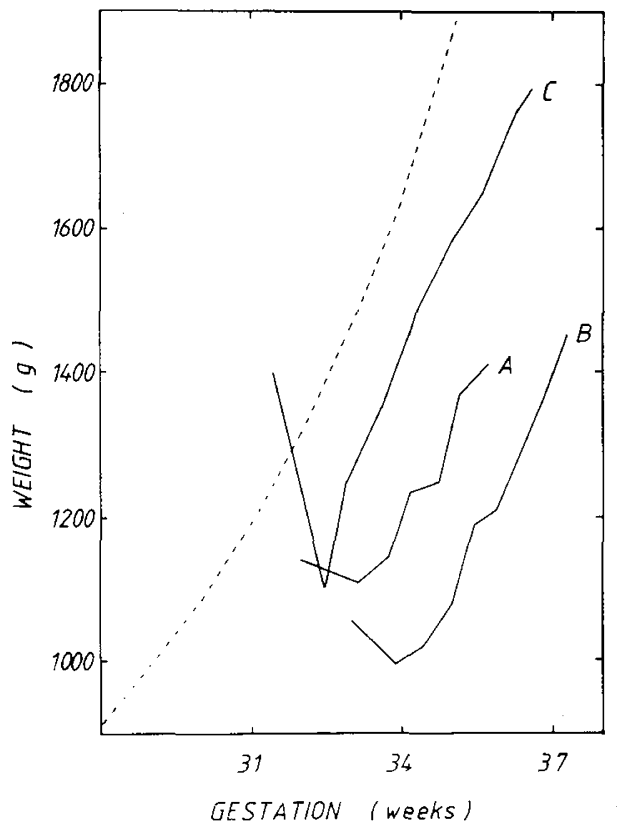

Fig. 3. Weight gain of the three infants as a function of gestational age. The dotted line represents the in utero weight gain of a male infant growing along the 10th percentile (28)

Table 6. Comparison of postnatal nitrogen accumulation with the calculated in utero accumulation

\begin{tabular}{ccccc}
\hline Study & $\begin{array}{c}\text { Gestation at } \\
\text { time of balance }\end{array}$ & $\begin{array}{c}\text { In utero } \\
\text { accumulation } \\
\left(\mathrm{mg} \mathrm{kg}^{-1} \mathrm{day}^{-1}\right)\end{array}$ & $\begin{array}{c}\text { Actual } \\
\left(\mathrm{mg} \mathrm{kg}^{-1} \mathrm{day}^{-1}\right)\end{array}$ & $\%$ \\
\hline A1 & 33.4 & 323 & 404 & 124 \\
$\mathrm{~A} 2$ & 34.4 & 327 & 293 & 96 \\
$\mathrm{~A} 3$ & 35.4 & 335 & 228 & 68 \\
& & & & \\
B1 & 35.1 & 332 & 271 & 82 \\
B2 & 36.5 & 344 & 259 & 75 \\
& & & & \\
C1 & 33.1 & 322 & 200 & 62 \\
C2 & 34.6 & 328 & 177 & 54 \\
C3 & 35.9 & 341 & 216 & 63 \\
\hline
\end{tabular}

minimal protein intake required to maintain zero balance is 96 $\mathrm{mg}$ nitrogen $\mathrm{kg}^{-1}$ day $^{-1}\left(0.6 \mathrm{~g}_{\text {protein }} \mathrm{kg}^{-1}\right.$ day $\left.^{-1}\right)$. This can be compared with other studies where breast milk has been used; for instance infants up to 6 months old require $127 \mathrm{mg}$ nitrogen $\mathrm{kg}^{-1}$ day $^{-1}$ (13), at $1 \mathrm{yr} 96 \mathrm{mg}$ nitrogen $\mathrm{kg}^{-1}$ day $^{-1}$ is needed (54) and children between 3 and 6 yr require $81 \mathrm{mg}$ nitrogen $\mathrm{kg}^{-1}$ day $^{-1}(12)$. All these values are much less than the figure obtained by Pencharz et al. (37) of $170 \mathrm{mg}$ nitrogen $\mathrm{kg}^{-1}$ day ${ }^{-1}$ (1.1 g protein $\mathrm{kg}^{-1} \mathrm{day}^{-1}$ ) using formulae. The value derived for obligatory losses is $67 \mathrm{mg}$ nitrogen $\mathrm{kg}^{-1}$ day $^{-1}$, which compares with $88 \mathrm{mg}$ nitrogen $\mathrm{kg}^{-1} \mathrm{day}^{-1}$ at 0 to 6 months (13) and $75 \mathrm{mg}$ nitrogen $\mathrm{kg}^{-1}$ $\mathrm{day}^{-1}$ at 3 to $6 \mathrm{yr}$ (12). In preterm infants fed formulae the figure of $145 \mathrm{mg}$ nitrogen $\mathrm{kg}^{-1}$ day $^{-1}$ was obtained by Pencharz et al. (37). The efficiency of nitrogen retention, after maintenance requirements had been met, 70\%, was the same as 0- to 6-month-old infants (13) but less than that for children 3 to 6 yr, 93\% (12).

\section{WEIGHT GAIN}

All infants lost weight after birth. This is in part due to the negative nitrogen balance associated with the undernutrition that follows birth (4) and in part to changes in body water (7). When

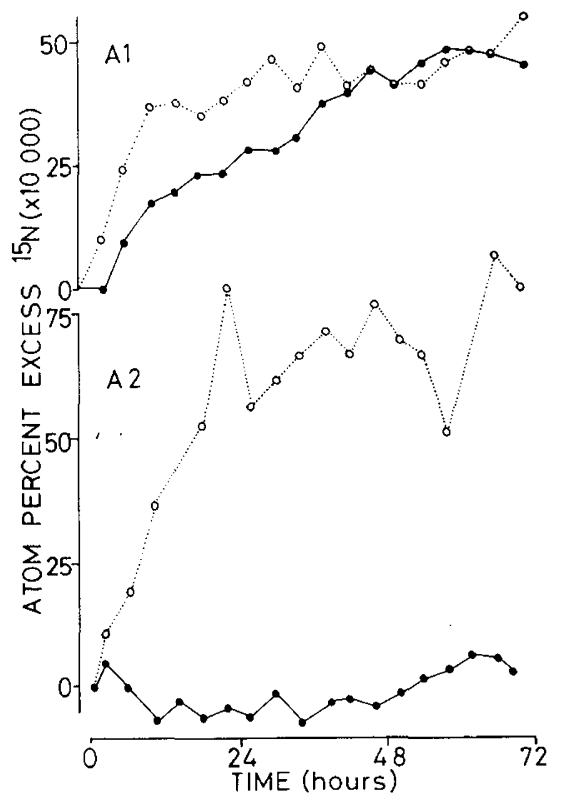

Fig. 4. The enrichment of urea $(\Theta)$ and ammonia $(O)$ in 4-hr specimens of urine for study $\mathrm{A} 1$ and $\mathrm{A} 2$. In study $\mathrm{A} 1$ urea and ammonia plateaux were identical whereas in study $A 2$ there was no enrichment of the urinary area.

Table 7. The isotopic enrichment in urinary, urea, ammonia, and residual nitrogen ${ }^{1}$

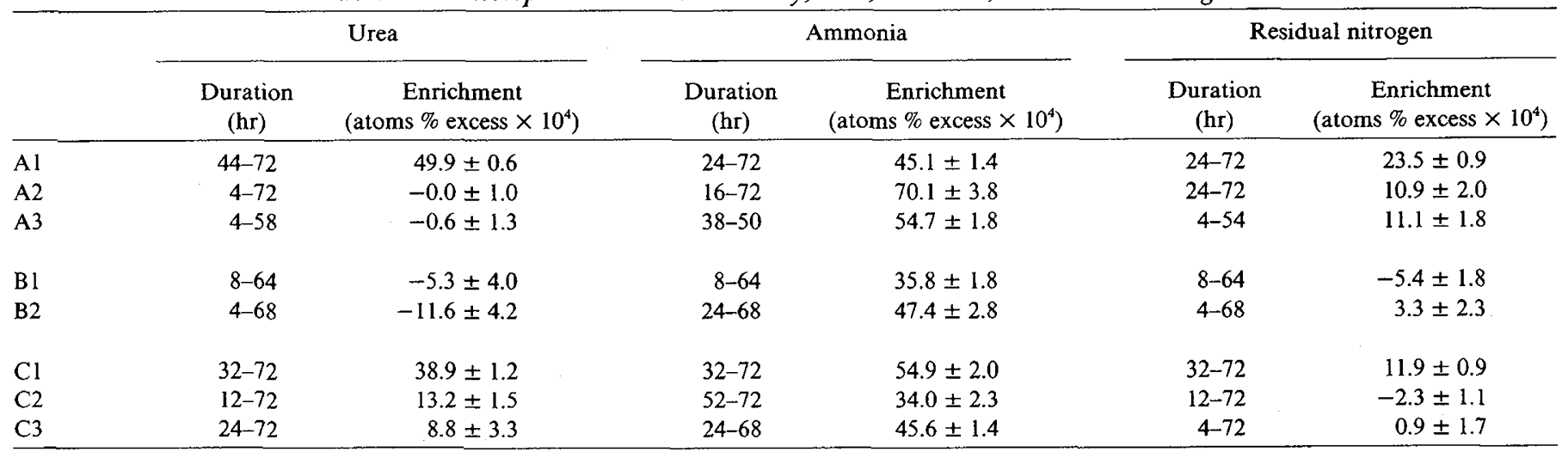

\footnotetext{
'There is a variation in the natural abundance in unenriched biologic samples (14) of \pm 14 . Therefore, an enrichment of greater than 15 is considered
} significant. Values are means \pm S.E. 
Table 8. Whole body nitrogen turnover (flux), protein synthesis, and protein breakdown

\begin{tabular}{|c|c|c|c|c|c|}
\hline & & & & Intake & Synthesis \\
\hline & nover & Synthesis & Dieakown & Turnover & Turnover \\
\hline (g nitr & $\left.\mathrm{kg}^{-1} \mathrm{day}^{-1}\right)$ & (g protein & $\mathrm{kg}^{-1}$ day $\left.^{-1}\right)$ & $(\%)$ & $(\%)$ \\
\hline Al & 2.04 & 11.2 & 8.7 & 32 & 88 \\
\hline $\mathrm{A} 2$ & 1.21 & 6.4 & 4.6 & 29 & 85 \\
\hline $\mathrm{A} 3$ & 1.32 & 7.0 & 5.7 & 30 & 77 \\
\hline Bl & 2.98 & 17.4 & 15.6 & 15 & 87 \\
\hline B2 & 1.99 & 11.1 & 9.6 & 23 & 83 \\
\hline $\mathrm{Cl}$ & 1.94 & 11.1 & 9.8 & 26 & 88 \\
\hline $\mathrm{C} 2$ & 1.85 & 10.8 & 9.6 & 17 & 93 \\
\hline C3 & 2.18 & 12.3 & 10.9 & 20 & 90 \\
\hline Mean & 1.94 & 10.91 & 9.34 & 25 & 86 \\
\hline S.D. & \pm 0.54 & \pm 3.38 & \pm 3.39 & \pm 8 & \pm 5 \\
\hline
\end{tabular}

growth was resumed they gained weight on average at a rate equivalent to that calculated for a foetus growing along a similar percentile. Thus they grew parallel to the percentile but did not catch up (Fig. 3).

\section{COMPOSITION OF WEIGHT GAIN}

All nitrogen balances are subject to systematic errors that tend to over estimate nitrogen retention (51). It is essential to bear this point in mind when making deductions about body composition from the results of balances. When nitrogen retention is compared with nitrogen accumulation by a foetus in utero of the same gestational age, growing along the 10 th percentile (Table 6) all but one value lie between 54 to $90 \%$ of the intrauterine accumulation rate. In balance $\mathrm{Al}$ the in utero accumulation rate was exceeded and in this case the protein intake was $40 \%$ higher than in the other balances (Table 4). If the nitrogen retention were compared with that of a foetus of the same weight, or of the same gestation, growing along the 50 th percentile relative accumulation of nitrogen would be even less. Since the measured retentions are almost certainly overestimates (vide supra) the real difference between the measured retentions and in utero accumulation is likely to be larger. Thus it can be concluded that as the weight gain was similar to that occurring in utero, the lean tissue deposition was probably less than lean tissue deposition in utero. Since lean tissue is thought to be preferentially deposited when all essential nutrients are available (39) a limitation of lean tissue deposition might imply the absence or restricted availability of one or more nutrients. The results of the protein turnover measurements suggested to us that we should consider the surprising hypothesis that glycine might be a limiting nutrient.

\section{PROTEIN TURNOVER}

In six of the eight studies urinary urea did not become enriched with ${ }^{15} \mathrm{~N}$ whereas the urinary ammonia did. This is an entirely new observation which has not been reported previously. This is also the first study where urine samples were analysed for a sufficient period of time to enable the simultaneous measurement of the rise of ammonia and urea to plateaux to be recorded. From unpublished data in six children completely recovered from protein energy malnutrition (16) we have shown that the ammonia and urea plateaux differed by less than $10 \%$, and consequently gave similar results for protein turnover. The model (38) requires that the proportion of label that enters protein and the end product, should be the same as the proportion of total nitrogen following these pathways. In the present study, there was no significant incorporation of labeled nitrogen into urea, except in balances $\mathrm{Al}$ and $\mathrm{Cl}$, therefore under prevailing conditions this underlying assumption could not be substantiated. To understand why it is necessary to consider glycine metabolism.

\section{GLYCINE METABOLISM}

The principle catabolic pathway for glycine is through a complex of enzymes found in the liver and kidney, known as the glycine cleavage system (26). One molecule of glycine is broken down to yield ammonia and a one carbon fragment. The one carbon fragment either forms methylene tetrahydrofolate, or is received by a second glycine molecule to form serine. Thus serine and glycine are readily interconvertible. This reaction sequence must have been established in the kidney of these infants since urinary ammonia was labeled (49). The fact that the urea was labeled in two of the early studies implies the reaction sequence was establied in the liver. In later studies glycine was not being catabolised in the liver, but rather was very efficiently retained for metabolic requirements. Glycine is required for the synthesis of proteins, porphyrins, nucleotides, creatine, glutathione, and for conjugating bile acids (31). It can be calculated from the data of Widdowson et al. (56) that the foetus requires at least $220 \mathrm{mg} \mathrm{kg}^{-1}$ $\mathrm{day}^{-1}$ of glycine for these purposes. Breast milk provides only 64 $\mathrm{mg} \mathrm{kg} \mathrm{day}^{-1}$ and although glycine may be obtained from serine or threonine, neither of these amino acids is abundant in breast milk (56). Therefore, there is a priori a need for significant endogenous synthesis of glycine in the extrauterine foetus.

\section{GLYCINE SYNTHESIS}

Glycine and serine can be interconverted through the glycine cleavage system (26). Both glycine and serine may be formed by transamination between alanine and glyoxylate and alanine and hydroxypyruvate, respectively, the enzymes being located in the peroxisomes of the liver $(34,35)$. In the rat the activity of both the alanine/glyoxylate and the alanine/hydroxypyruvate aminotransferase are very low during foetal life. At the time of birth the activity increases to reach a peak during the nursing period, falling to lower values at weaning $(44,45)$. Little is known about other pathways of glycine synthesis in the foetus. Theoretically glycine may be derived from threonine (30) or from glucose via phosphoserine to serine. The capacity of these pathways in the foetus is unknown, but neither is likely to be quantitatively important (31). Therefore, the availability of glycine might fall short of the metabolic requirements and hence glycine would become limiting for the preterm infant. The failure of glycine to label urea does not establish that glycine is growth limiting but it does suggest that in the liver there was little margin between supply and demand so that all dietary glycine was used for synthesis. Of all the studies Al stands out as worthy of note. It is serendipitous that the milk in this study had the highest protein concentration and the protein intake of $4.2 \mathrm{~g} \mathrm{~kg}^{-1} \mathrm{day}^{-1}$ was in the range associated with the highest growth rates by other workers $(5,10$, $11,17-19,36,37)$. In this study urea was labeled normally and gave turnover rates comparable to those calculated from the ammonia plateau. Since we do not know the amino acid composition of this milk we can only speculate that the glycine intake was adequate. In balance $\mathrm{Cl}$ the urea plateau (S) was two-thirds that of the ammonia and hence gave a value for protein turnover one and a half times that calculated from the ammonia plateau. In the remaining balances where urea was not labeled, $S$ (see "Patients and Methods") becomes zero and the calculated values for protein turnover infinite. These results show (whatever the interpretation one puts on it) that there exists in preterm infants a situation where ${ }^{15} \mathrm{~N}$-glycine fails to label the urea precursor pool adequately, and depending on the extent to which this occurs, protein turnover will be overestimated to a varying extent. It is relevant to note in this context that in rats maintained on a low protein diet ridiculously high values for protein turnover are found when using the method of Picou and Taylor-Roberts (38) and urea as an end product (50).

The results of Nicholson (32), though he used the single dose 
method of San Pietro and Rittenberg (40) were similar to ours. Using the enrichment of urea he found a mean value for protein synthesis of $12.7 \mathrm{~g}$ protein $\mathrm{kg}^{-1} \mathrm{day}^{-1}$, and turnover (Q) $2.3 \mathrm{~g}$ nitrogen $\mathrm{kg}^{-1}$ day ${ }^{-1}$. Using ammonia as an end product the values were $15.4 \mathrm{~g}$ protein $\mathrm{kg}^{-1} \mathrm{day}^{-1}$ and $2.75 \mathrm{~g}$ nitrogen $\mathrm{kg}^{-1}$ day $^{-1}$. These values are not significantly different from each other, and do not differ significantly $(P>0.05)$ from our results calculated from the ammonia plateau. Unfortunately Nicholson does not give the protein intake of his infants but since they were formula fed they may have had a higher protein intake than our infants, and together with their greater maturity this might account for the labeling of the urea precursor pool. Nicholson and Freeman (33) did show in a preterm infant that on a protein intake of $1.5 \mathrm{~g} \mathrm{~kg}^{-1}$ day $^{-1}$ the enrichment of urea after a single dose of ${ }^{15} \mathrm{~N}$-glycine was lower than on a protein intake of $4.4 \mathrm{~g} \mathrm{~kg}^{-1} \mathrm{day}^{-1}$, which is entirely compatible with our findings.

By contrast Pencharz et al. (37), using the continuous infusion method of Picou and Taylor-Roberts (38) and urea as an end product found values for turnover. ( $\dot{Q})$ of $4.35 \mathrm{~g}^{\text {nitrogen }} \mathrm{kg}^{-1}$ day $^{-1}$ and for protein synthesis of $26.3 \mathrm{~g}$ protein $\mathrm{kg}^{-1}$ day ${ }^{-1}$. These are twice the values reported by ourselves and Nicholson (32), and between 5 to 10 times the rates observed in older children and adults using the same method (52). We believe these values to be overestimates for the following reasons. From Figure 4 it is obvious that urea plateau is not reached for $48 \mathrm{hr}$. Pencharz et al. (37) stopped collecting urine at $34 \mathrm{hr}$ and calculated plateau enrichment from the mean of the last three urine specimens which were collected between 16 and $34 \mathrm{hr}$ after the onset of ${ }^{15} \mathrm{~N}$-glycine administration. They could not have reached plateau at this time, and both the figure they give and the results of their regression analysis confirm this. Indeed if they had used the plateaux calculated from their regression analysis they would have arrived at a value for turnover $(\dot{Q})$ of $2.5 \mathrm{~g}$ nitrogen $\mathrm{kg}^{-1} \mathrm{day}^{-1}$ and for protein synthesis of $15 \mathrm{~g}$ protein kg $\mathrm{day}^{-1}$; values very similar to those reported here and by Nicholson (32). A second possible factor tending to overestimate turnover $(\dot{Q})$ is the possibility, as we report here, that the ${ }^{15} \mathrm{~N}$-glycine was inadequately labeling the urea precursor pool. The fact that the urea was invariably labeled in their study might result from the higher protein intake of their infants or from differences in methodology. In order to separate the urea from the urinary ammonia Pencharz et al. (37) used Permutit. We have studied the use of Permutit exchange resin for the removal of ammonia and have found that cross-contamination with unbound ammonia may be of such magnitude that results such as ours could be completely overlooked. It is for this reason that we have preferred the removal of ammonia by aeration under alkaline conditions (23). Perhaps these considerations go some way to reconciling the differences reported in the literature.

About $60 \%$ of the glycine of the organism, is bound in collagen (30) where it comprises approximately $27 \%$ of the amino acid residues (1). Any limitation in the availability of glycine would account for the reduced deposition of collagen protein in long bones $(29)$ and restriction of longitudinal growth $(5,11)$ observed in preterm infants. Synderman et al (46) have shown improved growth when supplemental glycine is given as a source of non essential nitrogen to infants. Giordano et al. (15) have suggested that glycine may be essential in uraemic patients, for optimal haemoglobin synthesis.

\section{CONCLUSIONS}

(1) The protein requirement for nitrogen balance in preterm infants is not different from that in older infants. However, relatively more dietary nitrogen is required to ensure adequate nitrogen retention for growth.

(2) The preterm infants in this study did not gain weight statisfactorily when fed human breast milk, and the composition of the weight gained was relatively deficient in lean tissue. This might be the result of the low protein content of the milk, but the quality of the milk in terms of amino acid composition may not be optimal.
(3) The failure of ${ }^{15} \mathrm{~N}$ glycine to label urea indicated that endogenous synthesis of glycine might be insufficient to meet the demands of growth. If this should prove to be the case glycine would be a semiessential amino acid in this situation, and dietary supplementation may be necessary.

(4) The Picou and Taylor-Roberts model for measuring protein turnover, using ${ }^{15} \mathrm{~N}$-glycine and urea as the end product, is not applicable to all metabolic states. However, reliable results were obtained using ammonia as the end product.

(5) It may be possible to develop a sensitive method for measuring the requirement of essential amino acids, by administering the ${ }^{15} \mathrm{~N}$ labeled amino acid, and following the appearance of label in urea.

\section{REFERENCES AND NOTES}

1. Arnstein, H. R. U.: The metabolism of glycine. Adv. Protein Chem. 9: 1 (1952).

2. Atkinson, S. A., Anderson, G. H., and Bryan, M. H.: Human milk: comparison of the nitrogen composition in milk from mothers of premature and full term infants. Am. J. Clin. Nutr., 33: 811 (1980).

3. Atkinson, S. A., Bryan, M. H., and Anderson, G. H.: Human milk: Difference in nitrogen concentration in milk from mothers of term and preterm infants. J. Pediatr., 93: 67 (1978)

4. Auld, P. A. M., Bhangananda, P., and Mehta, S.: The influence of an early calorie intake with IV glucose on catabolism of premature infants. Pediatrics, 37: 592 (1966).

5. Babson, S. G., and Bramhall, J. L.: Diet and growth in the premature infant. The effect of different dietary intakes of ash-electrolyte and protein on weight gains and linear growth. J. Pediatr., 74: 890 (1969).

6. Barness, L. A., Barker, M. D., Guilbert, P., Torres, F. E., and Gyorgy, P.: Nitrogen metabolism in infants fed human and cows milk. J. Pediatr., 51: 29 (1957).

7. Cassady, G., and Milstead, R. R.: Antipyrine space studies and cell water estimates in infants of low birth weight. Pediatr. Res., 5: 673 (1971).

8. Cox, W. M., and Filer, L. J., J.: Protein intake for low birth weight infants. J. Pediatr., 74: 1016 (1969)

9. Dauncey, M. J., Shaw, J. C. L., and Urman, J.: The absorption and retention of magnesium, zinc and copper by low birth weight infants fed pasteurized human breast milk. Pediatr. Res., 11:991 (1977).

10. Davidson, M., Levine, S. Z., Bauer, C. H., and Dann, M.: Feeding studies in low birth weight infants. J. Pediatr., 70: 695 (1967).

11. Davies, D. P.: Adequacy of expressed breast milk for early growth of preterm infants. Arch. Dis. Child., 52: 296 (1977).

12. DeMaeyer, E. M., and Vanderborght, H. L.: Determination of the nutritive value of different protein foods in feeding African children. In: Progress in Meeting Protein Needs of Infants and Preschool Children. Vol. 843 (National Academy of Science, National Research Council, Washington, D.C., pp. 143-155, 1961).

13. Fomon, S. J., and May, C. D.: Metabolic studies of normal full term infants fed pasteurized human milk. Pediatrics, 22: 101 (1958).

14. Gaebler, O. H., Choitz, H. C., Vitti, T. G., and Vukmirovich, R.: Significance of ${ }^{15} \mathrm{~N}$ excess in nitrogenous compounds of biological origin. Can. J. Biochem. Physiol., 41 : 1089 (1963).

15. Giordano, C., De Santo, N. G., Rinaldi, S., De Pascale, C., and Pluvio, M.: Histidine and glycine essential amino acids in uremia. In: R. Kluthe G., Berlyne, B. Burton: Uremia. An International Conference on Pathogenesis, Diagnosis and Therapy (Georg Thieme Verlag, K. G., Stuttgart).

16. Golden, B. E., Golden, M. H. N., and Jackson, A. A.: (unpublished data).

17. Golden, M. H. N., Waterlow, J. C., and Picou, D.: Protein turnover synthesis and breakdown before and after recovery from protein-energy malnutrition. Clin. Sci. Mol. Med., 53: 473 (1977).

18. Goldman, H. I., Frendenthal, R., Holland, B., and Karelitz, M.D.: Clinical effects of two different levels of protein intake on low birth weight infants. J. Pediatr., 74: 881 (1969).

19. Gordon, H. H., Levine, S. Z., and McNamara, H.: Feedings of premature infants: a comparison of human and cows milk. Am. J. Dis. Child., 73: 442 (1947).

20. Gordon, H. H., Levine, S. Z., Wheatly, M. A., and Marples, E.: Respiratory metabolism in infancy and childhood. XX. The nitrogen metabolism in premature infants-comparative studies of human and cows milk. Am. J. Dis. Child., 54: 1030 (1937).

21. Gross, S. J., David, R. J., Bauman, L., and Tomarelli, R. M.: Nutritional composition of milk produced by mothers delivering preterm. J. Pediatr., 96: 641 (1980).

22. Jackson, A. A., and Golden, M. H. N.: ${ }^{15} \mathrm{~N}$-glycine metabolism in normal man: the metabolic $\alpha$-amino nitrogen pool. Clin. Sci. (Oxf.), 58: 517 (1980).

23. Jackson, A. A., Golden, M. H. N., Jahoor, P. F., and Landman, J. P.: The isolation of urea nitrogen and ammonia nitrogen from biological samples for mass spectrometry. Anal. Biochem., 105: 14 (1980).

24. Kaplan, A.: Urea nitrogen and urinary ammonia. In: S. Meites: Standard Methods of Clinical Chemistry. Vol. 5, pp. 245-256 (Academic Press, New York, 1965).

25. Kelly, H. J., Sloan, R. E., Hoffman, W., and Saunders, C.: Accumulation of nitrogen and six minerals in the human fetus during gestation. Hum. Biol., 23: 61 (1951).

26. Kikuchi, G.: The glycine cleavage system: composition, reaction mechanism and 
physiological significance. Mol. Cell. Biochem., I: 169 (1973).

27. Liu, H. Y., and Anderson, G. J.: A method for long term quantitative and fractional urine collection. J. Pediatr., 70: 276 (1967).

28. Lubchenko, L. O., Hansman, C., Dressler, M., and Boyd, E.: Intrauterine growth as estimated from live born birth weight data at 24 to 42 weeks of gestation. Pediatrics, 32: 793 (1963).

29. McIntosh, N., Shaw, J. C. L., and Taghizadeh, A.: Accumulation of nitrogen and collagen in the femur of the human foetus, and the effect of premature birth. Pediatr. Res., 11: 1023 (1977).

30. Meltzer, H. L., and Sprinson, D. B.: Studies in the metabolism of $l$-threonine. Fed. Proc. (abstracts), 9: 204 (1950)

31. Neuberger, A.: Aspects of the metabolism of glycine and of porphyrins. Biochem. J., 78: 1 (1961)

32. Nicholson, J. F.: Rate of protein synthesis in premature infants. Pediatr. Res., 4: 389 (1970).

33. Nicholson, J. F., and Freeman, J. M.: Metabolism of compounds labelled with ${ }^{15} \mathrm{~N}$ by an infant with congenital hyperammonemia. Pediatr. Res., 6: 252 (1972).

34. Noguchi, T., and Takada, Y.: Peroxisomal localisation of serine: pyruvate aminotransferase in human liver. J. Biol. Chem., 253: 7598 (1978).

35. Noguchi, T., and Takada, Y.: Peroxisomal localisation of alanine: glyoxylate aminotransferase in human liver. Arch. Biochem. Biophys., 196: 645 (1979).

36. Omans, W. B., Barness, L. A., Rose, C. S., and Gyorgy, P.: Prolonged feeding studies in premature infants. J. Pediatr., 59: 951 (1961).

37. Pencharz, P. B., Steffee, W. P., Cochran, W., Scrimshaw, N. S., Rand, W. M., and Young, V. R.: Protein metabolism in human neonates: nitrogen-balance studies, estimated obligatory losses of nitrogen and whole body turnover of nitrogen. Clin. Sci. Mol. Med., 52: 485 (1977).

38. Picou, D., and Taylor-Roberts, T.: The measurement of total protein synthesis and catabolism and nitrogen turnover in infants in different nutritional states and receiving different amounts of dietary protein. Clin. Sci. (Oxf.), 36: 283 (1969).

39. Rudman, D., Millikan, W. J., Richardson, T. J., Bixler, T. J., II, Stackhouse, J. and McGarrity, W. C.: Elemental balances during intravenous hyperalimentation in underweight adult subjects. J. Clin. Invest., 55: 94 (1975).

40. San Pietro, A., and Rittenberg, D.: A study of the rate of protein synthesis in humans II. Measurement of the metabolic pool and the rate of protein synthesis. J. Biol. Chem., 201: 457 (1953).

41. Schanler, R. J., and Oh, W.: Composition of breast milk obtained from mothers of premature infants as compared to breast milk obtained from donors. J. Pediatr., 96: 679 (1980).

42. Shaw, J. C. L.: Parenteral nutrition in the management of sick low birth weight infants. Pediatr. Clin. N. Am., 20: 333 (1973).

43. Shaw, J. C. L.: Evidence for defective skeletal mineralisation in low birth weight infants. The absorption of calcium and fat. Pediatrics, 57: 16 (1976).

44. Snell, K., and Walker, D. G.: The adaptive behaviour of isoenzyme forms of rat liver alanine aminotransferase during development. Biochem. J., 128: 403 (1972).

45. Snell, K., and Walker, D. G.: Regulation of $l$-serine dehydratase and $l$-serinepyruvate aminotransferase in the developing neonatal rat. Biochem. J., 144: 519 (1974).

46. Snyderman, S. E., Boyer, A., Koght, M.D., and Holt, L. E., Jr.: The protein requirement of the premature infant. I. The effect of protein intake on the retention of nitrogen. J. Pediat., 74: 872 (1969).

47. Synderman, S. E., Holt, L. E., Jr., Davies, J., Roitman, E., Boyer, A., and Balis, M. E.: "Unessential" nitrogen: a limiting factor for human growth. J. Nutr., 78: 1 (1962).

48. Sprinson, D. B., and Rittenberg, D.: The rate of utilization of ammonia for protein synthesis. J. Biol. Chem., 180: 707 (1949).

49. Squires, E. J., Hall, D. E., and Brosnan, J. T.: Arteriovenous differences for amino acids and lactate across kidneys of normal and acidotic rats. Biochem. J., 160: 125 (1976)

50. Stein, T. P., Oram-Smith, J. C., Leskiw, M. J., Wallace, H. W., Long, L. C., and Leonard, J. M.: Effect of nitrogen and calorie restriction on protein synthesis in the rat. Am. J. Physiol., 230: 1321 (1976).

51. Wallace, W. M., Weill, W. B., and Taylor, A.: The effect of variable protein and mineral intake upon body composition. Ciba Colloquia Ageing 4: 116 (1958).

52. Waterlow, J. C., Garlick, P. J., and Millward, D. J. Protein Turnover in Mammalian Tissues and in the Whole Body. (North Holland Publishing Co., Amsterdam, 1978).

53. Waterlow, J. C., Golden, M. H. N., and Garlick, P. J.: Protein turnover in man measured with ${ }^{15} \mathrm{~N}$ : comparison of end products and dose regimes. Am. J. Physiol., 235: El65 (1978)

54. Waterlow, J. C., and Wills, V. G.: Balance studies in malnourished Jamaican infants. 1. Absorption and retention of nitrogen and phosphorus. Br. J. Nutr., 14: $183(1960)$.

55. Widdowson, E. M., and Dickerson, J. W. T.: Chemical Composition of the body. In: C.L. Comar, F. Bronner: Mineral Metabolism. Vol. 2, Chap. 17. (Academic Press Inc., New York, 1961).

56. Widdowson, E. M., Southgate, D. A. T., and Hey, E. N.: Body Composition of the fetus and infant. In: H.K.A. Visser: Nutrition and Metabolism of the Fetus and Infant. (Martinus Nighoff Publishers b.v., The Hague, pp. 169-177, 1979).

57. The authors thank all the nurses who took such care with the balances and $\mathrm{L}$. Charley and J. Hibbert for technical assistance.

58. Requests for reprints should be addressed to: Dr. A. A. Jackson, Tropical Metabolism Research Unit, University of the West Indies, Mona, Kingston, Jamaica.

59. This research was supported by the Wellcome Trust.

60. Dr. M. H. N. Golden is on secondment from the London School of Hygiene and Tropical Medicine.

61. Received for publication February 2, 1981.

62. Accepted for publication April 2, 1981. 